\title{
Prepare to meet your partner
}

\author{
Cori Gorman, Cammie Edwards \& Robert Meister \\ More and more collaborations are born from partnering meetings, but the size and hectic pace of these events can \\ be overwhelming. To make the most of your time, go in prepared.
}

\begin{abstract}
ife science one-on-one partnering meetLings are one of the quickest, most efficient and most economical ways for small biotechs to find a partner. Currently, about 35 annual formal biotech partnering meetings are held worldwide, and professional life science conferences, such as the Biotechnology Industry Organization (BIO) International Convention, are increasingly adding oneon-one partnering to their programs. Here's what you need to know before you attend your next partnering meeting.
\end{abstract}

\section{What to expect}

When you think of a one-on-one partnering meeting, think of it as a sort of prescreened speed dating. For large companies, these meetings can be an efficient means of surveying what is new. For a small company, one-on-one partnering meetings are essential networking events. Although no two partnering meetings are alike, an earlystage company can typically have up to 35 30 -minute meetings in the course of 3 days of partnering. The partnering forums provide you with immediate access to senior pharmaceutical and biotech executives.

One of the most important aspects of partnering meetings these days is the partnering system software. Some are more intuitive than others, but the basic functionality is the same. The partnering software acts as a powerful data mining tool as well as a communication and scheduling guide that allows conference attendees to research potential collaborations and funding opportunities. The web-based systems allow attendees to search the company

Cori Gorman is president, Cammie Edwards is managing director and Robert Meister is director of corporate and marketing communications at DNA Gateway International LLC, San Francisco, California, USA. e-mail: robert@dnagateway.com and delegate profiles and the licensing options of attending companies. Once opportunities have been identified, you can communicate and schedule meetings directly with senior business and scientific management.

At the minimum, every partnering meeting offers one-on-one sessions. These are arranged through the software, allowing potential partners to search for each other via a range of criteria. Once queried, you may request meetings from those companies that meet the target partner profile. After meetings have been accepted, the software will schedule all the one-on-one meetings, accommodating participants' availabilities. These meetings are typically 30 minutes and take place in small cubicles that have enough room for about 4 people. They allow a quick gauge of synergies and allow for personal interactions between key players.

\section{Choosing the meeting}

Partnering can be a hefty financial and human resource commitment for a young company, so it pays to be organized (Supplementary Table 1 online). You'll want a well-planned partnering strategy for a maximum return on your time investment and a maximum number of meeting opportunities. The advice below should help you achieve this.

When deciding upon which partnering meetings to attend (Table 1), first consider the focus of the conference itself. It should be obvious to select a meeting based on strategic focus - don't attend an oncology meeting if your firm is focused on diabetes. But what's not so obvious is the importance of the partnering software: it should manage your list of selected target partners, request the status of the potential partners and facilitate all scheduling. Using the software should be intuitive, and you should move easily between searching company profiles and requesting meetings. It should also manage the correspondence between target companies clearly and effectively. If any of those pieces in the software system are missing, effective partnering will be hindered and you might want to avoid that particular conference. It is also important to review how the software will alert you to requests and replies to meet. For example, some conferences offer the option of having all meeting requests forwarded to your corporate e-mail account. This feature makes it easy to plan your efforts without the need to constantly log in to the partnering website. Some people prefer having meetings scheduled as soon as the other party has accepted the request. Some conferences, such as the BIO International Convention, post the schedule of meetings a week or so prior to the meeting. Both approaches work well, if you plan appropriately.

Also, examine the type and seniority of attendees when determining which meeting to attend. For small companies, the opportunity to speak with the key decision makers at potential partnering companies is especially important because there may be very limited opportunities for that elsewhere. Several of the European partnering meetings (which are a bit smaller) provide an excellent opportunity for those types of high-level connections for small biotech companies, and more and more venture capitalists are attending partnering meetings, often to assess emerging opportunities.

Size is important, too. BIO-Europe and BIO-Europe Spring are great meetings to attend because the meeting is very manageable (1,200-2,500 delegates). There are senior people in attendance and the other networking venues (for example: exhibit halls, receptions, workshops and panel discussions) are extremely well run and productive. Meetings also offer company presentation tracks, in which companies of all sizes present information on their products, partnering opportunities and corporate strategy. 
Table 1 The largest dedicated international partnering meetings

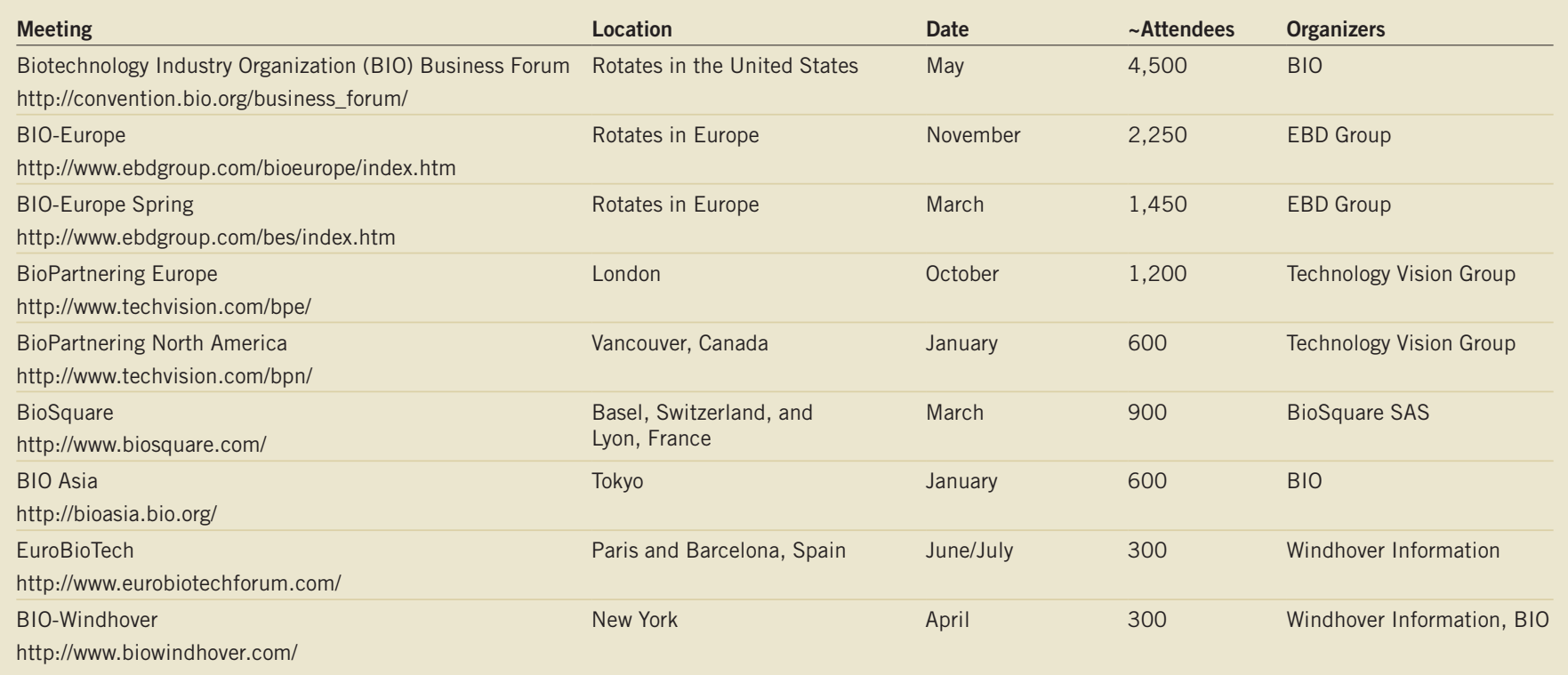

The biggest event of the year, though, is the BIO International Convention, and it's important because almost everyone attends. This meeting also has the biggest exhibit hall and the most presentations, as well as a vast range of networking events hosted both by BIO and numerous attending organizations. The $\mathrm{BIO}$ meeting is a good partnering venue because of the breadth and depth of attendees, presentation possibilities and networking venues; however, if you are new to partnering, the conference can be daunting: it's estimated that 20,000 attendees from more than 60 countries will attend this year's conference in Atlanta.

\section{Preparing to attend}

When you are sure you are attending, let others know (Supplementary Note 1 online),

\section{Box 1 Case study: Selexis}

Selexis is a company based in Geneva that provides solutions for boosting recombinant protein production in mammalian cells. It was founded in 2001, and a year later it went on the road seeking partners and clients for its technology (Selexis Genetic Elements) and services. It generated early business by tapping into personal networks to get introductions with target client companies, by attending speaking engagements to showcase its technology and by participating in exhibit hall booths. But in the long run, this was time consuming and relatively expensive for a small company. Each target client company had to be visited individually, and these companies were located throughout Europe and the United States. The exhibit hall booths and speaking engagements were not often attended by key decision makers.

In 2004, Selexis added one-on-one partnering meetings to its business development effort. Since then the company has maximized its success at meetings by ensuring that its profile is professional and complete, that invitations are out early and that it has done its homework on potential clients. In addition, Selexis prearranges meetings outside of the one-on-one partnering (which helped it close a license agreement with Diosynth, based in Morrisville, North Carolina), and it has an aggressive follow-up campaign for all potential clients identified from these meetings.

All of which means that, even with a small business development group, Selexis has been able to get access to key decision makers from a wide range of potential partner companies. The expense of traveling is now spent on companies that have already heard the initial pitch and have decided to move forward. In fact, $80 \%$ of all target company visits for Selexis are a result of one-on-one partnering. Furthermore, the success of these target company visits has increased. In 2002, $17 \%$ of the company visits translated into business deals; today, about $40 \%$ of the target company visits turn into deals.

and before you go, you must develop a strategy (Box 1). Learn as much as you can about the companies on your target list. Carry out competitive intelligence on your prospective partners before the meeting, but consider them carefully: if you are in the medical device field you will not want to have Amgen, of Thousand Oaks, California, or Genentech, of South San Francisco, California, on your list. However, if you see companies in attendance that you do not know about, research them, too, because you might unearth exactly what you are looking for in a partner. Amgen, for instance, has an effort in biomarkers, and Genentech has done sizeable deals in new chemical entities. Don't just focus on the pharma firms and big biotech, either. Consider medium-size companies, as many are looking to collaborate and in-license.

When you've done your research, go online and request meetings as early as possible. Typically, the partnering websites open one month before the meeting. Both US and European conferences set important partnering deadlines, so it's imperative that you meet the 'company background' and 'first round of meeting requests' deadlines. Requesting meetings early increases the probability that potential partners still have availability within their meeting schedule. Large companies, such as London-based GlaxoSmithKline (GSK), Paris-headquartered Sanofi-aventis, Eli Lilly of Indianapolis, Indiana, and Genentech, have schedules that fill up rapidly.

For your company background, make your information crisp, complete and professional (Supplementary Note 2 online). This is critical. The better you look, the more likely your 
meeting request will be accepted. Be as specific as possible in your profile about what elements are unique and compelling about your technology or drug. Be sure to have your profile online and completed early. The conference may use different software for the online posting, so be sure to check that your company profile displays correctly. For big pharma partners such as GSK or Sanofi, it is also important to be specific about whether you work in technology or in therapeutic development. These companies send teams of people to these conferences, so help them identify which of their team members should review your request. For instance, if Sanofi is partnering a target, be specific about whether you wish to discuss your opportunity with a vaccine or a therapeutics representative. For GSK and Amgen, the team is also separated into groups looking for new technologies versus therapeutics opportunities, so help them match your strategic interests with the best person to review your request. And use proactive keywords in your profile-it will allow other companies to find you.

Another tip: customize your request when you post it. Most large companies completely dismiss any request that is not customized to them. Take time to craft a specific and, if possible, personal message for each company you wish to meet. Amgen, for example, looks for a good summary of data and also an idea as to why you specifically wish to meet with them. Furthermore, it is a good idea to test out different tag lines in the subject line of your request to meet; we have been told that the Genentech partnering team often uses the tag line to rapidly sort requests as 'of interest' or 'not'.

Once you're up and running on the partnering site, check back at least weekly for new registrants that fit your target partner profile, and also provide any additional information requested by a potential partner. Often, more specific information may be requested to help a potential partner better understand the possible synergy between the companies. Amgen, for instance, often requests that a non-proprietary data package be made available prior to the actual conference, which assures that the Amgen representative most familiar with the field of technology actually takes the meeting at the conference. Then prepare your PowerPoint presentation, practice your pitch and make it quick and easy to understand. Remember that no confidential disclosure agreement is signed before the one-on-one partnering meetings.

When your formal partnering schedule is full, set up meetings outside the format. Meetings taken outside the business forum allow additional opportunities and greater in-depth discussions. Contact prospective partners whose information is in your company's internal database four to eight weeks before the meeting about availability for meetings outside of one-on-one partnering. It is often possible to get 5-15 additional high-quality meetings using this strategy.
Finally, exchange cell phone numbers so that both sides can handle schedule changes. This is easy to forget when using the partnering software, but it is important to be able to reach prospective partners in case of emergencies or late changes in schedule.

\section{During (and after) the meeting}

Don't attend meetings alone; always have a colleague from your company with you. Decide who is going to take the lead and let the other person take notes. Before your first partnering meeting begins, have hard copies of the profiles of all the companies you're seeing arranged in the order of your meetings. Remember to have plenty of business cards. The one-on-one partnering format features cubicles clearly marked with numbers. Some of the major biopharma companies may have larger partnering rooms with their names branded on the outside. In general, you can expect each cubical to be set up with four chairs, a table and a power strip. For those of you who are new, begin the dialog with your goals for the meeting and then discuss the next steps at the end of the meeting. If a company has requested a meeting with you, start by asking them what they are looking for. With only 25-30 minutes per meeting, logging on and powering up your computer is often not practical, so you should have simple, easy to understand data sheets available as a speaking aid.

But don't rely on just those meetings in cubicles-maximize the other networking

Table 2 Follow up; follow through. A timeline of the activities and deliverables that are required to maximize success at partnering meetings.

\begin{tabular}{|c|c|c|c|c|c|c|c|c|c|c|c|c|c|c|c|c|c|}
\hline & \multicolumn{9}{|c|}{ Week } & \multirow[b]{2}{*}{ Meeting } & \multirow[b]{2}{*}{1} & \multirow[b]{2}{*}{2} & \multirow[b]{2}{*}{3} & \multirow[b]{2}{*}{4} & \multirow[b]{2}{*}{5} & \multirow[b]{2}{*}{6} & \multirow[b]{2}{*}{7} \\
\hline & $-12-11-10-9$ & -8 & -7 & -6 & -5 & -4 & -3 & -2 & -1 & & & & & & & & \\
\hline \multicolumn{18}{|l|}{ Complete hotel and travel arrangements } \\
\hline \multicolumn{18}{|l|}{ Partnering press release } \\
\hline \multicolumn{18}{|l|}{ Develop corporate deck and collateral } \\
\hline \multicolumn{18}{|l|}{ Contact potential partners in internal database } \\
\hline \multicolumn{18}{|l|}{ Complete company background information (profile) } \\
\hline \multicolumn{18}{|l|}{ Competitive intelligence on partnering companies } \\
\hline \multicolumn{18}{|l|}{ Request meetings } \\
\hline \multicolumn{18}{|l|}{ Conference handbook \& CD-ROM closes } \\
\hline \multicolumn{18}{|l|}{ Meeting request deadline (first round of requests) } \\
\hline \multicolumn{18}{|l|}{ Practice your pitch } \\
\hline \multicolumn{18}{|l|}{ Preliminary partnering schedule available online } \\
\hline \multicolumn{18}{|l|}{ Meeting request deadline (final round of requests) } \\
\hline \multicolumn{18}{|l|}{ Complete meeting binders } \\
\hline \multicolumn{18}{|l|}{ Final pre-conference partnering schedule available online } \\
\hline \multicolumn{18}{|l|}{ Pre-conference meetings and activities } \\
\hline \multicolumn{18}{|l|}{ Partnering conference } \\
\hline \multicolumn{18}{|l|}{ Post-conference meetings and activities } \\
\hline \multicolumn{18}{|l|}{ Post-conference press release } \\
\hline \multicolumn{18}{|l|}{ Thank you emails } \\
\hline 'Plan of Action' emails and phone calls & & & & & & & & & & & & & & & & & \\
\hline
\end{tabular}


venues. Take full advantage of the social networking venues, presentation opportunities and exhibit areas. Particularly for new companies, take advantage of the opportunities to speak during the company presentation tracks or to participate in any panel discussions.

Even eating is an opportunity to network. Having lunch in the exhibit hall and attending a gala networking dinner are additional partnering opportunities. Not only can these events be very important in solidifying relationships made during the partnering session, but also they can provide opportunities to meet new potential partners.
When you're back in your office, follow up, follow up, follow up (Table 2). Immediately after the conference, send thank you e-mails with links to relevant pages on your company website, followed by 'next plan of action' e-mails or phone calls two to three weeks later. Remember that everyone needs time upon their return home to get their materials from the conference organized, and your contacts may need time to catch up on tasks at the office. This makes phone calls difficult to track; e-mails are best and provide a way to give additional information that may have been requested during the conference.

\section{Conclusions}

As big pharma moves away from the blockbuster business model and into niche-buster drugs, targeted therapies and personalized medicine, one-on-one partnering has become the most valuable business tool for quickly identifying new technologies and partnering opportunities.

With proper planning, an early-stage company will find one-on-one partnering to be the most efficient and economical way to establish high-value business connections.

Note: Supplementary information is available on the Nature Biotechnology website. 